\title{
Arrhenius Plot Analysis of the Temperature Effect on the Biodegradation Rate of 2-chloro-4-nitrophenol
}

\author{
Mohd Yunus Shukor \\ Department of Biochemistry, Faculty of Biotechnology and Biomolecular Sciences, Universiti Putra Malaysia \\ 43400 UPM Serdang, Selangor, Malaysia \\ Email: yunus.upm@gmail.com/mohdyunus@upm.edu.my
}

\begin{abstract}
Several models are available to determine the effect of temperature on the growth rate of microorganisms on substrates. An example is Arrhenius model, which is very popular because it has few parameters. For the first time, a discontinuous chevron-like graph of apparent activation energy based on the Arrhenius plot on the growth of 2-chloro-4-nitrophenol by Cupriavidus sp. is reported. The plot of $\ln m_{m}$ against 1/T shows a discontinuous chevron-like graph for the entire investigated temperature range with an inflection at $27.75^{\circ} \mathrm{C}$. This indicates that the existence of 2 activation energies for growth on 2chloro-4-nitrophenol ranges from 20 to $40^{\circ} \mathrm{C}$. Furthermore, a regression analysis from $20-25^{\circ} \mathrm{C}$ and $30-$ $40^{\circ} \mathrm{C}$ results in activation energies of $88.71 \mathrm{kJmol}^{-1}$ and $75.16 \mathrm{~kJ} \mathrm{~mol}^{-1}$, respectively. This is probably the first time a Chevron-like graph was observed for the Arrhenius plot on the effect of temperature on the growth rate of 2-chloro-4-nitrophenol.
\end{abstract}

Keywords: Arrhenius plot; breakpoint; Cupriavidus sp.; temperature; 2-chloro-4-nitrophenol-degrading

Article History: Received 20 September 2020; Received in revised form 23 October 2020; Accepted 16 November 2020; Available online 30 December 2020

How to Cite This Article: Shukor MY. 2020. Arrhenius plot analysis of the temperature effect on the biodegradation rate of 2-chloro4-nitrophenol. Biogenesis: Jurnal Ilmiah Biologi. vol 8(2): 219-224. doi: https://doi.org/10.24252/bio.v8i2.17419.

\section{INTRODUCTION}

Even at low doses, the toxicity of phenols and phenolic compounds is well known and their existence as toxins in the atmosphere is progressively recorded (Christen et al., 2012; Luo et al., 2012; Zulkharnain et al., 2013; Affandi et al., 2014; Bay et al., 2014; Ghazali \& Johari, 2015). Meanwhile, there are some physicochemical methods for the removal of these toxins, these include biodegradation, which is still being studied to date as an environmentally friendly process (Saravanan et al., 2008; Hasan \& Jabeen, 2015).

Furthermore, the typical representatives of chlorinated nitroaromatics include chloronitrophenols, which are commonly used in the synthesis of dyes, pesticides, fungicides, medicines, colorants, and others (Fuentes et al., 2013; Arora et al., 2018; Kasana \& Pandey, 2018). The most common CNP isomer that is used for the manufacture of the herbicide dicapthone and the fungicide nitrofungin is 2chloro-4-nitrophenol (Ghosh et al., 2010; Arora \& Jain, 2011; Pandey et al., 2011). This isomer has caused significant degradation to agricultural soils and water supplies due to its solubility and high mobility, which results in the extreme negative health effects on humans and animals. Therefore, the removal of 2chloro-4-nitrophenol from the environment has recently aroused wide biodegradation concern, which had been presented as a potential environmentally friendly method as several degrading bacterium have been isolated (Ghosh et al., 2010; Arora \& Jain, 2011; Pandey et al., 2011). Virtually all microorganisms are specifically affected by temperature due to their size. By regulating the internal biochemical pathways, temperature affects and influence microorganism physiology as an adaption tool to suit new environments. Therefore, temperature is a significant consideration which must be taken into account when studying the biodegradation of compounds. Furthermore, the Arrhenius model is a popular method in investigating the effects of temperature on bacterial growth rates. It is also used to quantify the apparent activation energy or $\Delta H^{*}$, for growth or degradation on substrates.

The values are normally falsely assumed to be constant, even though $\Delta H^{*}$ diverges either three or fourfold but conditional to the range of temperature being studied (Singh et al., 2008). Likewise, its applicability over the entire temperature of the bacterial process is 
constrained and may not be reliable (Reardon et al., 2000). However, this model is commonly used in the simulation of the temperature effect in a small range (Onysko et al., 2000). Furthermore, Arrhenius plot show a significant but an unknown breakpoint, which is a sudden shift of the activation energy (Angelova et al., 2008) when the growth rate is tested over a wide temperature.

In contrast to other models such as the Schulefield, Eyring and Urry, Sharpe and DeMichele, Arrhenius includes the least amount of parameters and therefore is generally accepted by most investigators (Onysko et al., 2000). Ratkowsky is another model competitor, however, its biological foundation tends to be insufficient and relies on the analytical study of the linear relationship between the temperature and the square root of the growth rate (Zwietering et al., 1991). Therefore, Arrhenius models are commonly used in explaining the effects of temperature on bacterial growth. The estimation of its parameter is derived from the linear regression of Arrhenius plot.

In this analysis, activation energies for the degradation of 2-chloro-4-nitrophenol by a bacterium demonstrated a breakpoint indicating that it has more more than one possible value. Furthermore, the activation energy is not only fundamentally interesting, but it is very helpful in predicting the biodegradation and transport of phenols during bioremediation works.

\section{MATERIALS AND METHODS}

Activation energy of growth on 2-chloro4-nitrophenol. The data on the rate of biodegradation in Table 1 (Min et al., 2018) at various temperatures was processed using Webplotdigitizer 2.5 (Rohatgi, 2018). Furthermore, Arrhenius equation (Arrhenius, 1889) was utilized to model the effect of temperature on biodegradation rate as follows,

$$
\mu=A e^{-\frac{E_{a}}{R T}}
$$

Where,

$\mathrm{T}$ (Kelvins or $\mathrm{K}={ }^{\circ} \mathrm{C}+273.15$ ) is the absolute temperature, $\quad R\left(8.314 \mathrm{~J} \mathrm{~mol}^{-1} \mathrm{~K}^{-1}\right)$ is the universal gas constant, $E_{a}\left(\mathrm{~kJ} \mathrm{~mol}^{-1}\right)$ is the activation energy while the physical meaning of
A relates to the rate constant of which all of the participating molecules acquires enough energy before the reaction $(\mathrm{Ea}=0)$. The linearized form the equation is attained by plotting the normal logarithms of the growth rate against $1 / \mathrm{T}$ as follows;

$$
\ln \mu=\ln A-\frac{E_{a}}{R} \cdot \frac{1}{T}
$$

The analysis of the breakpoint, statistical evaluation of the resultant Arrhenius plot, and regression coefficients estimation were carried out using the two-part least-squares linear regression (Angelova et al., 2008; Gafar et al., 2019).

\section{RESULTS AND DISCUSSION}

A Chevron-like graph was obtained when plotting $\ln \mu_{m}$ against $1 / \mathrm{T}$ showing a discontinuous part for the whole temperature range studied (Fig. 1). The presence of an inflection point is an important observation found near the midrange at $27.75^{\circ} \mathrm{C}$. At 20 $25^{\circ} \mathrm{C}$, the regression analysis result, which is summarized in Table 1 indicates that the growth on 2-chloro-4-nitrophenol exhibited an activation energy of $75.165 \mathrm{~kJ} \mathrm{~mol}^{-1}$ while at $30-40^{\circ} \mathrm{C}$, it was $88.711 \mathrm{~kJ} \mathrm{~mol}^{-1}$. The overlapped $95 \%$ confidence interval between these two values indicate that there is no significant difference in terms of activation energy value. Furthermore, the apparent Arrhenius activation energy for growth on 2chloro-4-nitrophenol for the temperature studied is within the range of the reported values in the literature for halogenated phenol and is much higher than several phenoldegrading bacteria, which ranged from 28.4 to $57.74 \mathrm{Kj} \mathrm{mol}^{-1}$ (Table 2). It appears that more energy is needed to break the halogenated bonds. Moreover, increasing the temperature reduces the energy needed. This is probably the reason for the lower activation energies observed in the degradation of polychlorinated biphenyl (PCB) by the thermophilic Bacillus sp. JF8, where two activation energies; $12.1 \mathrm{~kJ}$ $\mathrm{mol}^{-1}$ and $31.4 \mathrm{~kJ} \mathrm{~mol}^{-1}$ were reported for 50$70^{\circ} \mathrm{C}$ and $20-46^{\circ} \mathrm{C}$, respectively (MukerjeeDhar et al., 2005). However, this study shows the breakpoint for growth on 2-chloro-4nitrophenol for the first time. 


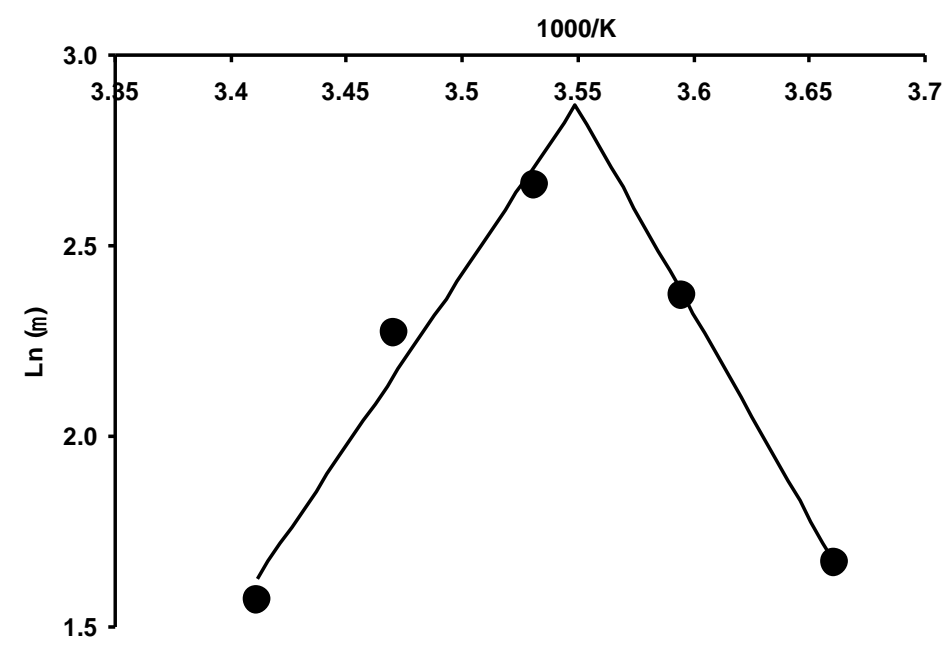

Fig. 1. Arrhenius plot of 2-chloro-4-nitrophenol biodegradation rate

The higher the activation energy, the more energy is required by the bacterium to metabolize phenolics. Based on Table 2, Pseudomonas species tend to be more energetic than other organisms in degrading phenol. However, this does not mean a better phenol degradation efficiency compared to other bacteria. As mentioned above, the activation energy, which ranges from 33.5 to $50.3 \mathrm{~kJ} \mathrm{~mol}^{-}$ ${ }^{1}$ are far higher than those needed by mesophilic (Tchobanoglous \& Schoeder, 1985).

Furthermore, the criticism of Arrhenius model is based on the observation that the activation energy, is generally believed to be a constant value when it is actually not, and it is dependent on the temperature selected as observed in the present study (Ratkowsky et al., 1982). Therefore, the model is observational, which is not easily understood as the complicated interacting biological processes occurs simultaneously in thousands at the same time. Strictly speaking, the activation energy value is not used in chemical reactions but is the measurement of the overall temperature response of the microbe (Melin et al., 1997). Despite these challenges, the model is still popular among scientists worldwide.

The sudden transition or breaking point of the activation energy as temperature shift is an integral physiology of microorganisms and has been documented using different substrates. For instance, the biodegradation of dye (Angelova et al., 2008), Nitrosomonas cells nitrification rate (Benyahia \& Polomarkaki, 2005), bacterial utilization of glucose (Kuhn et al., 1980), utilization of ethanol (Mutafov \& Minkevich, 1986), biodegradation of EDTA (Minkevich et al., 2006), biomass yield (Chistyakova et al., 1983; Mutafov \& Minkevich, 1986), and the thermal inactivation of microorganisms (Verrips \& Kwast, 1977; Kuhn et al., 1980).

Table 1. The two-part linear regression analysis for the Arrhenius plot of phenol growth rate

\begin{tabular}{|c|c|}
\hline $\begin{array}{l}\text { Distribution of the } \\
\text { experimental points }\end{array}$ & $\begin{array}{l}\text { Three points to the } \\
\text { left, two points to the } \\
\text { right } \\
\text { Left part }\end{array}$ \\
\hline Temperature range ${ }^{\circ} \mathrm{C}$ & 30,35 and 40 \\
\hline Regression equation & $y=9.0452 x-29.23$ \\
\hline $\begin{array}{l}\text { Coefficient of } \\
\text { determination }\end{array}$ & 0.970 \\
\hline $\tan \theta \pm$ Standard error & $9.045 \pm 1.602$ \\
\hline$E_{a} \pm$ Standard error, $\mathrm{kJ} \mathrm{mol}^{-}$ & $75.165 \pm 13.312$ \\
\hline t-Statistic & 65535 \\
\hline \multirow[t]{2}{*}{ Degrees of freedom } & 2 \\
\hline & Right part \\
\hline Temperature range ${ }^{\circ} \mathrm{C}$ & 20 and 25 \\
\hline Regression equation & $y=-10.675 x+40.75$ \\
\hline $\begin{array}{l}\text { Coefficient of } \\
\text { determination }\end{array}$ & 1.00 \\
\hline Tan $\theta \pm$ Standard error & $-10.675 \pm 0.000$ \\
\hline $\begin{array}{l}E_{a} \pm \text { Standard error, } \mathrm{kJ} \mathrm{mol}^{-} \\
-\end{array}$ & $88.711 \pm 0.00$ \\
\hline t-Statistic & 5.64 \\
\hline Degrees of freedom & 1 \\
\hline $\begin{array}{l}\text { Intersection coordinates, }(x, \\
\text { y) }\end{array}$ & $\begin{array}{l}\text { Break points data } \\
(3.549,2.868)\end{array}$ \\
\hline Break point temperature ${ }^{\circ} \mathrm{C}$ & 27.75 \\
\hline
\end{tabular}


Table 2. Arrhenius temperature characteristics for growth on phenol and phenolics

\begin{tabular}{|c|c|c|c|c|}
\hline Microorganisms & $\begin{array}{l}\text { Temperature } \\
\text { range }\left({ }^{\circ} \mathrm{C}\right)\end{array}$ & Substrate & $\begin{array}{l}\Delta H^{*} \text { apparent } \\
\text { activation energy } \\
\left(\mathrm{Kj} \mathrm{mol}^{-1}\right)\end{array}$ & Ref \\
\hline activated sludge & $10-20$ & phenol & 39.0 & $\begin{array}{l}\text { Benedek \& Farkas, } \\
1970\end{array}$ \\
\hline $\begin{array}{l}\text { Selanastrum } \\
\text { capricornutum }\end{array}$ & $20-28$ & phenol & 28.4 & Reynolds et al., 1974 \\
\hline $\begin{array}{l}\text { aerobic fluidized-bed } \\
\text { reactors (FBRs) }\end{array}$ & $14-16.5$ & $\begin{array}{l}\text { 2,4,6-trichlorophenol } \\
\text { (TCP), 2,3,4,6- } \\
\text { tetrachlorophenol } \\
\text { (TeCP), and } \\
\text { pentachlorophenol } \\
\text { (PCP) }\end{array}$ & $\begin{array}{l}\text { TCP and TeCP } \\
126-194 \\
\text { PCP } \\
59-130\end{array}$ & Melin et al., 1998 \\
\hline $\begin{array}{l}\text { Pseudomonas } \\
\text { putida } \mathrm{Q} 5\end{array}$ & $10-25$ & phenol & 61.6 & Onysko et al., 2000 \\
\hline Acclimated cultures & $15-30$ & nonylphenol & 42.7 & Jahan et al., 2008 \\
\hline $\begin{array}{l}\text { Pseudomonas putida } \\
\text { MTCC } 1194\end{array}$ & $15-30$ & phenol & 57.74 & $\begin{array}{l}\text { Bandyopadhyay et al., } \\
1981\end{array}$ \\
\hline Bacillus sp. JF8 & $20-70$ & $\begin{array}{l}\text { polychlorinated biphenyl } \\
\text { (PCB) }\end{array}$ & $\begin{array}{l}12.1\left(20-46^{\circ} \mathrm{C}\right) \\
31.4\left(50-70^{\circ} \mathrm{C}\right)\end{array}$ & $\begin{array}{l}\text { Mukerjee-Dhar et al., } \\
2005\end{array}$ \\
\hline $\begin{array}{l}\text { Pseudomonas sp. } \\
\text { AQ5-04 }\end{array}$ & $15-45$ & phenol & $\begin{array}{l}38.92\left(15-30^{\circ} \mathrm{C}\right) \\
11.34\left(35-45^{\circ} \mathrm{C}\right)\end{array}$ & Aisami et al., 2017 \\
\hline $\begin{array}{l}\text { Pseudomonas sp. } \\
\text { Strain DrYJ7 }\end{array}$ & & acrylamide & $14.96\left(10-20^{\circ} \mathrm{C}\right)$ & Gafar et al., 2019 \\
\hline $\begin{array}{l}\text { Cupriavidus sp. strain } \\
\text { CNP-8 }\end{array}$ & $20-40$ & 2-chloro-4-nitrophenol & $\begin{array}{l}75.16\left(30-40^{\circ} \mathrm{C}\right) \\
88.71\left(20-25^{\circ} \mathrm{C}\right)\end{array}$ & This study \\
\hline
\end{tabular}

What triggers the transformation is still unclear, however, two theories are proposed. The first is that a difference in the physical properties of water is induced during the transition at $15^{\circ} \mathrm{C}$ (Kuhn et al., 1980). The second is the theory of "bottle neck", which indicates a small rate reactions across a series of enzyme in succession. The fact that the Arrhenius breakpoint temperatures have been observed to be truly diverse seems not to support the first hypothesis (Angelova et al., 2008). Since each of the chained enzyme has special thermal properties, it is difficult to prove the "bottle-neck" theory. Moreover, the cell membrane varies depending on the surrounding temperature, and this need to be taken into account (Ceuterick et al., 1978). From the many hypothesis, the "bottle neck" continues to be prevalent among scholars (Mutafov and Minkevich, 1986; Angelova et al., 2008).

\section{CONCLUSION}

This is the first study to demonstrate that the required activation energy for the biodegradation of 2-chloro-4-nitrophenol by
Cupriavidus sp. strain CNP-8 displays a broken profile with the two observed in the Arrhenius plot. This discontinuous activation energy covers the temperature range of 20 to 25 and 30 to $40^{\circ} \mathrm{C}$ with values that are not significantly different. However, the quantum are much higher than the typical energies observed in mesophilic microorganisms. Furthermore, the halogenated bond is postulated to hold much higher activation energy to be broken. Finally, further investigations are been carried out particularly on the use of parameters to determine the effects of temperature on growth kinetics.

\section{REFERENCES}

Affandi IE, Suratman NH, Abdullah S, Ahmad WA, Zakaria ZA. 2014. Degradation of oil and grease from high-strength industrial effluents using locally isolated aerobic biosurfactant-producing bacteria. International Biodeterioration and Biodegradation. vol 95: 33-40. doi: https://doi.org/10.1016/j.ibiod.2014.04.009.

Aisami A, Yasid NA, Johari WLW, Shukor MY. 2017. Estimation of the Q10 value; the temperature coefficient for the growth of Pseudomonas sp. aq5- 
04 on phenol. Bioremediation Science and Technology Research. vol 5: 24-26.

Angelova B, Avramova T, Stefanova L, Mutafov S. 2008. Temperature effect on bacterial azo bond reduction kinetics: an Arrhenius plot analysis. Biodegradation. vol 19: 387-393. doi: https://doi.org/10.1007/s10532-007-9144-4.

Arora PK, Jain RK. 2011. Pathway for degradation of 2chloro-4-nitrophenol in Arthrobacter sp. SJCon. Current Microbiology. vol 63: 568-573. doi: https://doi.org/10.1007/s00284-011-0022-2.

Arora PK, Srivastava A, Garg SK, Singh VP. 2018. Recent advances in degradation of chloronitrophenols. Bioresource Technology. vol 250: 902-909. doi: https://doi.org/10.1016/j.biortech.2017.12.007.

Arrhenius S. 1889. Über die Reaktionsgeschwindigkeit bei der Inversion von Rohrzucker durch Säuren. Zeitschrift Für Physikalische Chemie. vol 4: 226248. doi: https://doi.org/10.1515/zpch-1889-0416.

Bandyopadhyay SK, Chatterjee K, Tiwari RK, Mitra A, Banerjee A, Ghosh KK, Chatterjee GC. 1981. Biochemical studies on molybdenum toxicity in rats: effects of high protein feeding. International Journal for Vitamin and Nutrition Research. vol 51: 401-409.

Bay HH, Lim CK, Kee TC, Ware I, Chan GF, Shahir S, Ibrahim Z. 2014. Decolourisation of acid orange 7 recalcitrant auto-oxidation coloured by-products using an acclimatised mixed bacterial culture. Environmental Science and Pollution Research. vol 21: 3891-3906. doi: https://doi.org/10.1007/s11356-013-2331-4.

Benedek P, Farkas P. 1970. Influence of temperature on the reactions of the activated sludge process. Proceedings of the International Symposium on Water Pollution Control in Cold Climates. vol 44(7): 1433-1442.

Benyahia F, Polomarkaki R. 2005. Mass transfer and kinetic studies under no cell growth conditions in nitrification using alginate gel immobilized Nitrosomonas. Process Biochemistry. vol 40: 1251-1262.

doi: https://doi.org/10.1016/j.procbio.2004.05.011.

Ceuterick F, Peeters J, Heremans K, De Smed, H, Olbrechts H. 1978. Effect of high pressure, detergents and phaospholipase on the break in the arrhenius plot of Azotobacter nitrogenase. European Journal of Biochemistry vol 87: 401-407.

Chistyakova TA, Minkevich IG, Eroshin VK. 1983. Growth of the thermotolerant yeast, Candida valida, on ethanol: Dependences of maximal growth rate and cell biomass yield on temperature. European Journal of Applied Microbiology and Biotechnology. vol 18: 225-228.

Christen P, Vega A, Casalot L, Simon G, Auria R. 2012. Kinetics of aerobic phenol biodegradation by the acidophilic and hyperthermophilic archaeon Sulfolobus solfataricus 98/2. Biochemical
Engineering Journal. vol 62: 56-61. doi: https://doi.org/10.1016/j.bej.2011.12.012.

Fuentes MS, Briceño GE, Saez JM, Benimeli CS, Diez MC, Amoroso MJ. 2013. Enhanced removal of a pesticides mixture by single cultures and consortia of free and immobilized streptomyces strains. BioMed Research International. vol 2013: 1-9. doi: https://doi.org/10.1155/2013/392573.

Gafar AA, Manogaran M, Yasid NA, Halmi MIE, Shukor MY, Othman AR. 2019. Arrhenius plot analysis, temperature coefficient and Q10 value estimation for the effect of temperature on the growth rate on acrylamide by the Antarctic bacterium Pseudomonas sp. strain DRYJ7. Journal of Environmental Microbiology and Toxicology. vol 7: 27-31.

Ghazali FM, Johari WLW. 2015. The occurrence and analysis of bisphenol A (BPA) in environmental samples - a review. Journal of Biochemistry, Microbiology and Biotechnology. vol 3: 30-38.

Ghosh A, Khurana M, Chauhan A, Takeo M, Chakraborti A, Jain R. 2010. Degradation of 4-nitrophenol, 2chloro-4-nitrophenol, and 2,4-dinitrophenol by Rhodococcus imtechensis strain RKJ300. Environmental Science \& Technology. vol 44: 1069-1077. doi: https://doi.org/10.1021/es9034123.

Hasan SA, Jabeen S. 2015. Degradation kinetics and pathway of phenol by Pseudomonas and Bacillus species. Biotechnology and Biotechnological Equipment. vol 29: 45-53. doi: https://dx.doi.org/10.1080\%2F13102818.2014.991 638.

Jahan K, Ordóñez R, Ramachandran R, Balzer S, Stern M. 2008. Modeling biodegradation of nonylphenol. Water, Air, \& Soil Pollution: Focus. vol 8: 395404. doi: https://doi.org/10.1007/s11267-007-91484.

Kasana RC, Pandey CB. 2018. Exiguobacterium: an overview of a versatile genus with potential in industry and agriculture. Critical Reviews in Biotechnology. vol 38(1): 141-156. doi: https://doi.org/10.1080/07388551.2017.1312273.

Kuhn HJ, Cometta S, Fiechter A. 1980. Effects of growth temperature on maximal specific growth rate, yield, maintenance, and death rate in glucose-limited continuous culture of the thermophilic Bacillus caldotenax. European Journal of Applied Microbiology and Biotechnology. vol 10: 303-315.

Luo ZH, Pang KL, Wu YR, Gu JD, Chow RK, Vrijmoed LLP. 2012. Degradation of phthalate esters by Fusarium sp. DMT-5-3 and Trichosporon sp. DMI5-1 isolated from mangrove sediments. In: Biology of marine fungi. Berlin: Springer. pp 299-328.

Melin ES, Ferguson JF, Puhakka JA. 1997. Pentachlorophenol biodegradation kinetics of an oligotrophic fluidized-bed enrichment culture. Applied Microbiology and Biotechnology vol 47: 675-682. 
Melin, E.S., Jarvinen, K.T. and Puhakka, J.A. 1998. Effects of temperature on chlorophenol biodegradation kinetics in fluidized-bed reactors with different biomass carriers. Water Research 32: 81-90.

Min J, Wang J, Chen W, Hu X. 2018. Biodegradation of 2-chloro-4-nitrophenol via a hydroxyquinol pathway by a Gram-negative bacterium, Cupriavidus sp. strain CNP-8. AMB Express. vol 8: 1-11. doi: https://doi.org/10.1186/s13568-0180574-7.

Minkevich IG, Satroutdinov AD, Dedyukhina EG, Chistyakova TI, Kaparullina EN, Koshelev AV, Okunev ON. 2006. The effect of temperature on bacterial degradation of EDTA in $\mathrm{pH}$-auxostat. World Journal of Microbiology and Biotechnology. vol 22: 1205-1213. doi: https://doi.org/10.1007/s11274-006-9162-0.

Mukerjee-Dhar G, Shimura M, Miyazawa D, Kimbara K, Hatta T. 2005. Bph genes of the thermophilic PCB degrader, Bacillus sp. JF8: characterization of the divergent ring-hydroxylating dioxygenase and hydrolase genes upstream of the Mn-dependent BphC. Microbiology. vol 151: 4139-4151. doi: https://doi.org/10.1099/mic.0.28437-0.

Mutafov SB, Minkevich IG. 1986. Temperature effect on the growth of Candida utilis VLM-Y-2332 on ethanol. Comptes Rendus de L'Academie Bulgare Des Sciences. vol 39: 71-74.

Onysko KA, Budman HM, Robinson CW. 2000. Effect of temperature on the inhibition kinetics of phenol biodegradation by Pseudomonas putida Q5. Biotechnology and Bioengineering. vol 70: 291299. doi: https://doi.org/10.1002/10970290(20001105)70:3\%3C291::aidbit6\%3E3.0.co;2-y.

Pandey J, Heipieper HJ, Chauhan A, Arora PK, Prakash D, Takeo M, Jain RK. 2011. Reductive dehalogenation mediated initiation of aerobic degradation of 2-chloro-4-nitrophenol (2C4NP) by Burkholderia sp. strain SJ98. Applied Microbiology and Biotechnology. vol 92: 597-607. doi: https://doi.org/10.1007/s00253-011-3254-y.

Ratkowsky DA, Olley J, McMeekin TA, Ball A. 1982. Relationship between temperature and growth rate of bacterial cultures. Journal of Bacteriology. vol 149: $1-5$.

Reardon KF, Mosteller DC, Bull Rogers JD. 2000. Biodegradation kinetics of benzene, toluene, and phenol as single and mixed substrates for Pseudomonas putida F 1. Biotechnology and Bioengineering. vol 69: 385-400. doi: https://doi.org/10.1002/10970290(20000820)69:4\%3C385::aidbit5\%3E3.0.co;2-q.

Reynolds JH, Middlebrooks EJ, Procella DB. 1974. Temperature-toxicity model for oil refinery waste. Journal of the Environmental Engineering Division. vol 100: 557-576.

Rohatgi A. 2018. WebPlotDigitizer-Extract data from plots, images, and maps. http://arohatgi. info/WebPlotDigitizer.

Saravanan P, Pakshirajan K, Saha P. 2008. Growth kinetics of an indigenous mixed microbial consortium during phenol degradation in a batch reactor. Bioresource Technology. vol 99: 205-209. doi: https://doi.org/10.1016/j.biortech.2006.11.045.

Singh RK, Kumar S, Kumar S, Kumar A. 2008. Biodegradation kinetic studies for the removal of $\mathrm{p}$ cresol from wastewater using Gliomastix indicus MTCC 3869. Biochemical Engineering Journal. vol 40: 293-303. doi: https://doi.org/10.1016/j.bej.2007.12.015.

Tchobanoglous G, Schoeder ED. 1985. Water Quality: Characteristics, Modeling and Modification, $1^{\text {st }}$ ed. London: Pearson Reading Mass.

Verrips CT, Kwast RH. 1977. Heat resistance of Citrobacter freundii in media with various water activities. European Journal of Applied Microbiology. vol 4: 225-231.

Zulkharnain A, Maeda R, Omori T. 2013. Expression, purification and characterization of meta-cleavage enzyme carbabb from Novosphiongobium sp. KA1. Journal of Biochemistry, Microbiology and Biotechnology. vol 1: 11-16.

Zwietering MH, de Koos JT, Hasenack BE, de Witt JC, van't Riet K. 1991. Modeling of bacterial growth as a function of temperature. Applied and Environmental Microbiology. vol 57: 1094-1101. 